\title{
FACTORS INFLUENCING HEALTH RELATED QUALITY OF GERIATRIC PATIENTS' LIVES WITH CHRONIC HEPATITIS C VIRUS (HCV)
}

\author{
Saeer M. Tannous, Rasha A. Fouad, and Nagwa A. Ibrahim \\ Department of Gerontological Nursing, Faculty of Nursing, Alexandria University
}

\begin{abstract}
Background: Hepatitis $\mathrm{C}$ virus continues to be a major public health problem all over the world especially in Egypt. Chronic hepatitis C impairs health related quality of life (HRQOL) even in the absence of severe morbidity; this suggests that, there are other factors can affect HRQOL of elderly patients with HCV. Identifying these factors can lead to improve their health related quality of life. So this study aimed to determine factors influencing HRQOL of geriatric patients with HCV. Three tools were used for data collection: Socio-demographic and clinical data structured interview schedule, Knowledge related to HCV structured interview schedule, and HRQOL of HCV patients structured interview schedule. It can be concluded that, chronic hepatitis $\mathrm{C}$ virus affected negatively most of the dimensions of patients' generic HRQOL. The majority of the study subjects have only partial knowledge about the disease and its mode of transmission.
\end{abstract}

Key Words: Elderly - Hepatitis C-Quality of life-nurse' role

\section{INTRODUCTION}

Hepatitis $\mathrm{C}$ virus (HCV) affects all age groups and continues to be a major public health problem. According to the World Health Organization 2011, about 130-170 million people are chronically infected with hepatitis $\mathrm{C}$ virus, and more than 350000 people die from hepatitis C-related liver diseases each year. ${ }^{(1)}$

Anti-hepatitis $\mathrm{C}$ virus positivity has been detected in up to $30-60 \%$ in some countries ${ }^{(2)}$. The burden of chronic hepatitis $\mathrm{C}$ virus infection in elderly persons is expected to increase significantly in the United States during the next 2 decades. (3) Over time, approximately twenty percent of patients with chronic $\mathrm{HCV}$ often will progress to cirrhosis and $5 \%$ of patients will develop hepatocellular carcinoma. $(4,5)$ The prevalence of $\mathrm{HCV}$ infection in the elderly varies among different studies. According to a study done in the USA 2009, the prevalence of positive HCV antibody was found to be $0.9 \%$ and $1.0 \%$ in subjects who were in the age groups of 60 to 69 years, and 70 years and older, respectively. ${ }^{(6)}$ Moreover, According to the 1999-2002 National Health and Nutrition Examination Survey IV, the prevalence of antibodies against HCV (anti-HCV) was 1.6\% in the general population aged $\geq 6$ years' ${ }^{(7)}$ the highest rate of infection was observed in the cohort aged 4549 years, and among persons aged $\geq 60$ years, $1 \%$ were anti-HCV positive. Thus, of 44 million US residents $\geq 60$ years old, 440,000 might be anti-HCV positive. (8) The risk of $\mathrm{HCV}$ increases significantly with age, probably owing to agerelated changes in the ability to repair DNA, and to the prolonged interval from the time of infection, exposure to blood or blood products, baby boomer's drug use, and physiology of the disease and the treatment ${ }^{(9)}$

In contrast to the United States, other countries such as Japan (10) Italy ${ }^{(11)}$ and France ${ }^{(12)}$ the prevalence of $\mathrm{HCV}$ infection is low among children and young adults, but it increases at the age of 40 years and continues to increase during aging. In a community-based study in Japan, the prevalence of anti-HCV seropositivity was $3 \%$ in the $20-29$-year-old group and increased to $41 \%$ among persons aged 80-89 years. (10) In Italy, the prevalence of positive HCV antibody was found to be around $11 \%$ of the total subjects with a mean age of 79.31 years and twenty percent of infected individuals' progress to chronic HCV. ${ }^{(11)}$

In Egypt HCV recently emerged as a major public health hazard. The current population in Egypt is about 80 million, $14.7 \%$ of this population are infected with this virus. This is an underestimated number because it does not include the number of people who have been infected and under 15 years, or over 60 years of age ${ }^{(13)}$. However, dramatic healthcare budget constraints limit access to the costly treatment ${ }^{(14)}$. According to a research study done on Egyptian people in 2008, and the WHO statistics 2008, the Egyptian rural population recorded the highest prevalence of HCV in the world and Genotype 4 is the most prevalent genotype in Egypt. ${ }^{(15,16)} \mathrm{A}$ previous study in Cairo 2004 indicated that sources of infection are previous admitted to hospital or clinic 54\%, parenteral antischistosomal therapy $6.5 \%$, and blood transfusion $6.1 \%$. (17) However, many patients acquire hepatitis $\mathrm{C}$ without any known exposure to blood or to drug use. (18) 
Geriatric patients with $\mathrm{HCV}$ infection have several aging related changes considered as limitations to be studied adequately. These changes make them excluded from several clinical trials due to fear of dealing with more severe hepatitis $C$ related side effects. ${ }^{(19)}$ Among these changes, decreased GFR and decreased liver function that might cause severe hemolytic anemia with Ribavirin and interactions of Interferon which were approved for treatment with multi-adverse effects. (20, 21$)$ Previous western studies have reported a consistent and marked reduction in health related quality of life among chronic hepatitis C patients as compared with nationally representative samples of adults particularly in physical health-related domains. ${ }^{(22)}$

Chronic HCV in elderly patients is associated with nonspecific symptoms such as fatigue, irritability, nausea, anorexia, abdominal discomfort and headache. These symptoms have been directly associated with the reduction of HRQOL as evidenced by reductions in functional health status, psychological status and general health perception measures. Moreover, with advancing age, older adults frequently report fatigue, sleep disturbances, memory difficulties, gastrointestinal problems, dry skin, eyes and mouth. It is difficult to tell what is caused by $\mathrm{HCV}$, and what age is related ${ }^{(23)}$.Several studies about chronic HCV infection showed a significant reduction in HRQOL measures. A study done in London 2009 mentioned that even in the absence of liver disease, chronic infection with the hepatitis $\mathrm{C}$ virus (HCV) compromises HRQOL with profound negative impacts on both physical and mental well-being ${ }^{(24)}$.

Several factors can affect HRQOL of older adult patients with chronic HCV. These include physical, psychological, socioeconomic and demographic factors, in addition to poor knowledge about the disease. ${ }^{(25)}$ It has been recently reported in the USA 2009 that patients with a history of depression, who were not receiving antidepressants, are more likely to fail treatment for genotype $2 / 3 \mathrm{HCV}$ and will need additional support. ${ }^{(24)}$ Moreover, prior studies have shown that HCV-infected individuals have limited knowledge of HCV disease, and improvement in HCV knowledge is effective at reducing transmission or highrisk behaviors for transmission and can influence a patient's decision to explore and initiate HCV therapy and consequently affecting their quality of life. $(22,25)$

Identifying factors that influence HRQOL in elderly patients with chronic HCV will enable the Interdisciplinary team including the gerontological nurse to play a significant role in providing holistic care for these patients, and improving the patient knowledge for possible sources of HCV transmission,. Thus, enhancing their health related quality of life. This care will be individualized, taking into consideration all aspects of the elder patients' life, (physical, psychological and social) in order to enhance their HRQOL. 26,27$)$

\section{AIM OF THE STUDY}

The aim of this research was to determine factors influencing health related quality of geriatric patients' lives with $\mathrm{HCV}$.
Research question:

What are the factors that influence health related quality of geriatric patients' lives with chronic HCV?

\section{MATERIALS AND METHOD}

\section{MATERIALS}

Design: This study followed a descriptive correlational design.

Setting: The study was carried out in the outpatient clinic of the two selected hospitals affiliated to the ministry of health in Alexandria, Egypt

Subjects: The subjects of the present study comprised 200 consecutive elderly patients, from both sex, aged 60 years and older, able to communicate effectively and diagnosed with hepatitis $\mathrm{C}$ for at least six months.

Tools: the following three tools were used to collect data for this research:

Tool I: Geriatric patients with chronic HCV's Sociodemographic and clinical data structured interview schedule: was developed by the researchers based on relevant literature and included information about socio-demographic characteristics such as age, sex, marital status, education, residence, job before retirement, and monthly income.

Tool II: Knowledge related to HCV structured interview schedule: was developed by Twafike E $2011^{(28)}$ and includes questions that assess patients' general knowledge about the disease. Responses to this tool are yes, no and do not know. The scoring system was as follows: Score of $75 \%$ and more for the correct answers indicates good knowledge, score of 50 to less than $75 \%$ for the correct answers indicates moderate knowledge, and score less than $50 \%$ for the correct answer indicates poor knowledge.

Tool III: Health related quality of HCV patients' lives structured interview schedule: was developed by Tawfike $\mathrm{E}^{(28)} 2011$, the modified version of the SF-36 scale was used in this study to measure the eight dimensions of physical functioning, bodily pain, mental health, social functioning, role limitation due to emotional problems, vitality, role limitation due to physical health, and general health status. The obtained information reflected how patients feel and their ability to perform usual activities. Responses to the questions in this part ranged from 1-3. The score of each of the eight domains was calculated by summing the scores of its items. The total score was obtained by summing the scores of the eight domains. The total score ranged from 0-100 and the scoring system is as follows: scores of $66.7 \%$ or more indicate high quality of life, scores of $33.4 \%$ to $66.6 \%$ indicate moderate quality of life, and scores of less than $33.3 \%$ indicate poor quality of life. 
Method: Official letters were issued from the Faculty of Nursing, Alexandria University to the administrators of the study settings to obtain their permission to carry out the study. The tools used in this study were tested for reliability by using Cronbach's Alpha Test. The reliability of tool II was $\mathrm{R}=0.71$ and for tool III was $\mathrm{R}=0.90$. A pilot study was carried out on twenty geriatric patients (were excluded from the study subjects) to test clarity, feasibility and the applicability of the study tools. The researchers used to meet the patients individually in the waiting room, explain the purpose of the study and obtain the informed consent. It was possible to interview 4-6 elderly daily. Time of the interview ranged from 30-45 minutes. Data collection started from the twentieth of August until mid- December 2011.

\section{Ethical considerations:}

An informed written consent from the study subjects to participate in the study was being obtained after explanation of the study purpose. Confidentiality of the collected data, privacy and anonymity of the study subjects and the right to withdraw at any time was assured.

\section{STATISTICAL ANALYSIS}

After data collection, data were coded and transformed into specially designed forms as to be suitable for computer feeding. All entered data were verified for any error. The SPSS V 19.0 was used for the analysis of the data. Frequency tables and cross tabulations were used to illustrate the results of categorical data which were later analyzed using the chi square test or Fisher's Exact Test (FET). $\mathrm{P}$ value $\leq 0.05$ was considered a cutoff for significance.

\section{RESULTS}

Part 1: Socio-demographic and clinical data of the study subjects

Table (1) shows the distribution of the study subjects according to their socio-demographic data. The age of the study subjects ranged from 60 to 84 years, with a mean of $63.14 \pm 3.8 .3$ years. Males constituted $60 \%$ of the study subjects, $80.5 \%$ of them were married, $46.5 \%$ were illiterate, and the agricultural work was reported by $32 \%$ of them. It is observed that the monthly income of the study subjects ranged from less than 500 L.E to more than 1000 L.E with a mean of $583.1 \pm 44.77 .85 .5 \%$ of the study subjects lived in their own homes with their families, The duration of having HCV ranged from less than one year to more than 10 years with a mean of $54.18 \pm$ 43.9 months.

Table (1): Distribution of the study subjects according to their Socio- demographic and clinical data

\begin{tabular}{|c|c|c|c|}
\hline 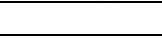 & Items & No $=200$ & Percent \% \\
\hline \multicolumn{4}{|c|}{ 1-Age in years : } \\
\hline O & $60-$ & 141 & 70.5 \\
\hline O & $65-$ & 50 & 25 \\
\hline 0 & $70+$ & 9 & 4.5 \\
\hline \multicolumn{4}{|c|}{ Mean \pm SD $=63.14 \pm 3.803$ years } \\
\hline \multirow[t]{3}{*}{ 2-Sex } & & & \\
\hline & Male & 120 & 60 \\
\hline & Female & 80 & 40 \\
\hline \multicolumn{4}{|c|}{ 3-Marital status } \\
\hline & Married & 161 & 80.5 \\
\hline & Widowed & 34 & 17 \\
\hline & Divorced & 5 & 2.5 \\
\hline \multicolumn{4}{|c|}{ 4-Level of Education } \\
\hline & Illiterate & 93 & 46.5 \\
\hline & Read and write & 21 & 10.5 \\
\hline & Basic education & 47 & 23.5 \\
\hline & Secondary & 28 & 14 \\
\hline & University and higher & 11 & 5.5 \\
\hline \multicolumn{4}{|c|}{ 5-Occupation before retirement } \\
\hline & Farmer & 64 & 32 \\
\hline & Employee & 61 & 30.5 \\
\hline & House wife & 60 & 30 \\
\hline & Manual worker & 11 & 5.5 \\
\hline & Private Work & 4 & 2 \\
\hline \multicolumn{4}{|c|}{ 6-Monthly Income (\$) } \\
\hline & $<500$ & 77 & 38.5 \\
\hline & $500-$ & 108 & 54 \\
\hline & $1000+$ & 15 & 7.5 \\
\hline \multicolumn{4}{|c|}{ Mean \pm SD $=583.1 \pm 44.77$} \\
\hline \multicolumn{4}{|c|}{ 7-Source of income } \\
\hline & Pension & 121 & 60.5 \\
\hline & Sons & 62 & 31 \\
\hline & Current job & 13 & 6.5 \\
\hline & Relatives & 4 & 2 \\
\hline \multicolumn{4}{|c|}{ 8-Living condition } \\
\hline & Own home & 171 & 85.5 \\
\hline & With sons & 23 & 11.5 \\
\hline & Alone & 6 & 3 \\
\hline \multirow[t]{2}{*}{ 9-Residence } & Urban & 115 & 57.5 \\
\hline & Rural & 85 & 42.5 \\
\hline \multicolumn{4}{|c|}{ 10- Duration since HCV diagnosis } \\
\hline$<1$ & jear & 26 & 13 \\
\hline $1<$ & yrs & 65 & 32.5 \\
\hline & $0 \mathrm{yrs}$ & 83 & 41.5 \\
\hline 10 & & 26 & 13 \\
\hline
\end{tabular}


Part II: Knowledge of the study subjects about HCV

Table (2) illustrates the distribution of the study subjects according to their knowledge about chronic hepatitis $\mathrm{C}$. Regarding the subjects' knowledge about the question ( $a$ person may be infected without appearance of symptoms), $65.5 \%$ of the study subjects answered correctly. As regards their knowledge about (patient with no symptoms can infect others), $57.2 \%$ of those who gave correct answer to the previous question answered correctly. As for their knowledge about the presence of HCV vaccination, $40 \%$ reported (do not know). With regard to subjects' knowledge about risk factors that damage the liver, $95.5 \%$ of the study subjects provided correct answer about drug abuse, followed by $94 \%$ alcohol intake.

Table (3) demonstrates the distribution of the study subjects according to their knowledge about modes of transmission of HCV. Above ninety percent of the study subjects gave correct answers about modes of HCV transmission via non sterilized dental equipment, nonsterilized surgical equipment, needle stick injury, sharing personal equipment, handshake, hugging, embracing, and contaminated food. Above seventy percent of the study subjects gave correct answers about repeated syringe use, drug abuse injection, blood transfusion, cough and sneezing, and sucking insects.

\section{Part III: Health related quality of the study subjects' lives}

Table (4a) shows the distribution of the study subjects according to the generic health related quality of life domains. Regarding the Physical functioning, the table revealed that $82 \%$ of the study subjects reported extreme limitation in the vigorous activities such as running and lighting heavy objects. Concerning the role limitation, 52 $\%$ of the study subjects faced difficulty to perform needed work. Regarding bodily pain, $54.4 \%$ reported that the pain extremely interfere with normal work. Concerning the general health, $75 \%$ of the study subjects reported that they are not as healthy as anybody they know. With regard to the health status of the study subjects compared to one year ago, $82.5 \%$ reported it to be worse.

Table (4b) shows the distribution of the study subjects according to the generic HRQOL- mental component. Regarding the vitality, $59.5 \%$ of the study subjects reported (not feeling full of live all the time) and 52.5\% (feeling tired some of the time). Health conditions interfered with social and normal activities all the time were reported by $(30.0 \%, 35 \%)$ of the study subjects respectively. As regards mental health, $58 \%$ of the study subjects reported (being very nervous for some of the time during the past four weeks).

Table (5) shows the distribution of the study subjects according to the generic HRQOL physical component and mental one. The majority of the study subject $(84.5 \%$, $88.5 \%$ ) had a moderate health related quality of lifephysical and mental component respectively.

Table (6) illustrates the relationship between sociodemographic data and the subjects' total level of knowledge about the disease. $78 \%$ of the study subjects who are at 60 to less than 65 years provided moderate level of knowledge about the disease with no statistical significant relation being observed between age and the total level of subjects' knowledge about the disease, $\mathrm{P}=$ 0.727 . More than one half $(58 \%)$ of females and $24 \%$ of males reported poor level of knowledge about the disease with a statistical significant relation was found between sex and the level of subjects' knowledge about the disease $\mathrm{P}=0.031$. Highly statistical significant relationships were found between educational level, occupation before retirement, and monthly income and subjects' knowledge score, $\mathrm{P}=0.000$.

Table (2): Distribution of the study subjects according to their knowledge about chronic hepatitis C

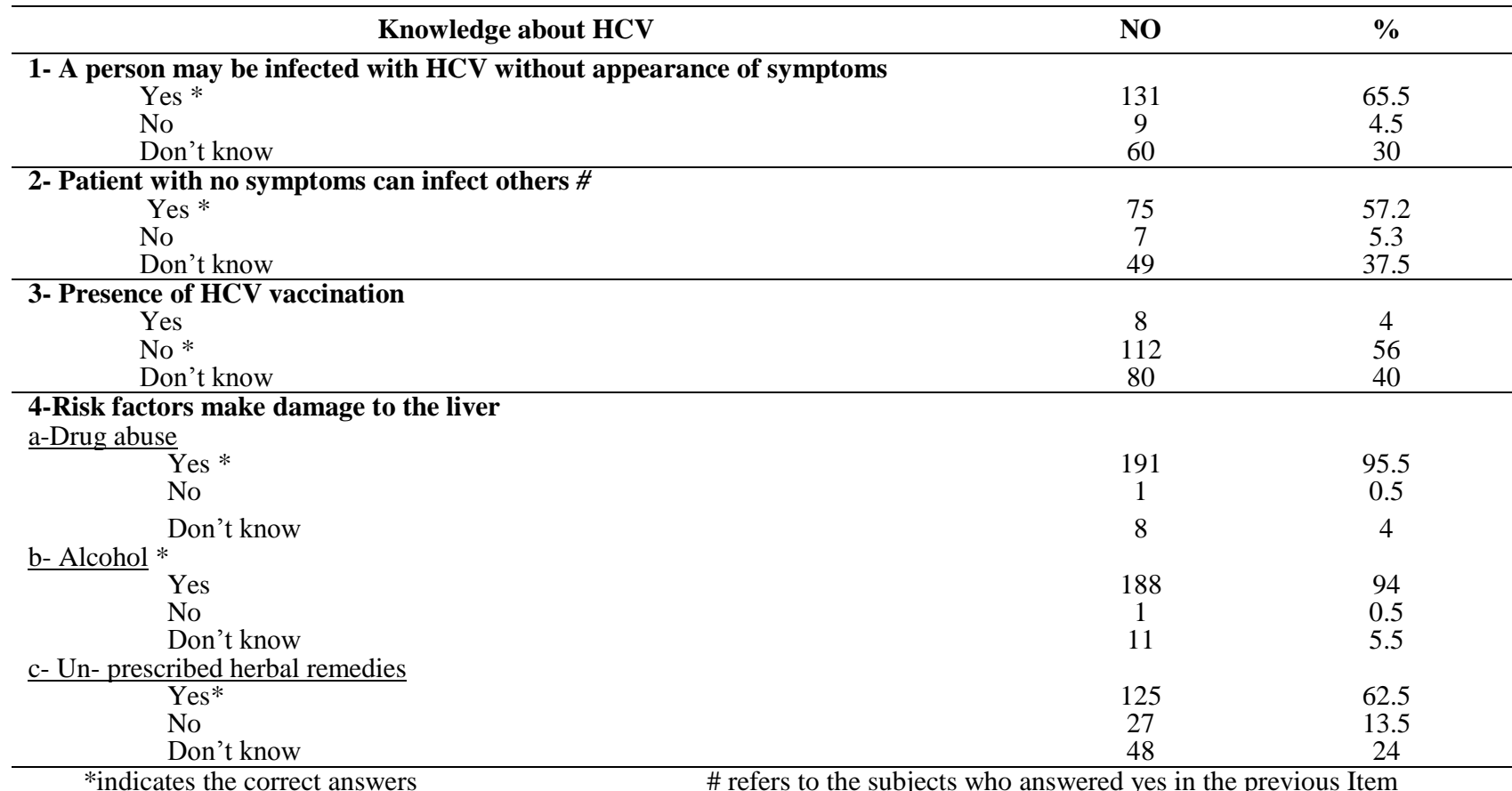

JMRI, 2015, Vol.36 No.2: (50-61) 
Table (3): Distribution of the study subjects according to their knowledge about HCV modes of transmission

\begin{tabular}{|c|c|c|c|}
\hline & Mode of transmission & $\mathrm{NO}=\mathbf{2 0 0}$ & $\%$ \\
\hline \multicolumn{4}{|c|}{ 1- Non- sterilized dental equipment } \\
\hline o & Correct answer & 199 & 99.5 \\
\hline 0 & Wrong answer & 0 & 0 \\
\hline 0 & Do not know & 1 & 0.5 \\
\hline \multicolumn{4}{|c|}{ 2- Non-sterilized surgical equipment } \\
\hline 0 & Correct answer & 196 & 98 \\
\hline o & Wrong answer & 0 & 0 \\
\hline$\circ$ & Do not know & 4 & 2 \\
\hline \multicolumn{4}{|c|}{ 3- Needle stick injury } \\
\hline o & Correct answer & 195 & 97.5 \\
\hline o & Wrong answer & 0 & 0 \\
\hline ○ & Do not know & 5 & 2.5 \\
\hline \multicolumn{4}{|c|}{ 4- Sharing sharp personal equipment } \\
\hline o & Correct answer & 191 & 95,5 \\
\hline ○ & Wrong answer & 4 & 2 \\
\hline o & Do not know & 5 & 2,5 \\
\hline \multicolumn{4}{|c|}{ 5- Handshake / hugging, Embracing } \\
\hline$\circ$ & Correct answer & 183 & 91.5 \\
\hline ० & Wrong answer & 14 & 7 \\
\hline o & Do not know & 3 & 1.5 \\
\hline \multicolumn{4}{|c|}{ 6- Contaminated food } \\
\hline$\circ$ & Correct answer & 181 & 90.5 \\
\hline o & Wrong answer & 16 & 8 \\
\hline o & Do not know & 3 & 1.5 \\
\hline \multicolumn{4}{|c|}{ 7- Organ donation } \\
\hline 0 & Correct answer & 176 & 88 \\
\hline o & Wrong answer & 0 & 0 \\
\hline 0 & Do not know & 24 & 12 \\
\hline 5-Mode & f transmission & $\mathrm{NO}=200$ & $\%$ \\
\hline \multicolumn{4}{|c|}{ 8- Repeated syringe use } \\
\hline 0 & Correct answer & 174 & 87 \\
\hline o & Wrong answer & 2 & 1 \\
\hline o & Do not know & 24 & 12 \\
\hline \multicolumn{4}{|c|}{ 9- drug abuse by injection } \\
\hline$\circ$ & Correct answer & 156 & 78 \\
\hline o & Wrong answer & 12 & 6 \\
\hline$\circ$ & Do not know & 32 & 16 \\
\hline \multicolumn{4}{|c|}{ 10- Blood transfusion } \\
\hline o & Correct answer & 155 & 77,5 \\
\hline 0 & Wrong answer & 5 & 2,5 \\
\hline$\circ$ & Do not know & 40 & 20 \\
\hline \multicolumn{4}{|c|}{ 11- Cough and sneezing } \\
\hline o & Correct answer & 153 & 76,5 \\
\hline$\circ$ & Wrong answer & 15 & 7,5 \\
\hline$\circ$ & Do not know & 32 & 16 \\
\hline \multicolumn{4}{|c|}{ 12- Sucking insects } \\
\hline$\circ$ & Correct answer & 68 & 72 \\
\hline ○ & Wrong answer & 62 & 16 \\
\hline$\circ$ & Do not know & 70 & 12 \\
\hline \multicolumn{4}{|c|}{ 13- Sharing dishes spoon and forks with the patient } \\
\hline o & Correct answer & 48 & 24 \\
\hline o & Wrong answer & 138 & 69 \\
\hline$\circ$ & Do not know & 14 & 7 \\
\hline \multicolumn{4}{|c|}{ 14- Breast-feeding } \\
\hline$\circ$ & Correct answer & 32 & 15 \\
\hline o & Wrong answer & 144 & 72 \\
\hline$\circ$ & Do not know & 34 & 12 \\
\hline \multicolumn{4}{|c|}{ 15- Mother to her fetus } \\
\hline o & Correct answer & 23 & 11.5 \\
\hline ० & Wrong answer & 100 & 50 \\
\hline$\circ$ & Do not know & 77 & 38.5 \\
\hline
\end{tabular}


Table (4a) distribution of the study subjects according to the generic HRQOL SF 36

\begin{tabular}{|c|c|c|c|c|c|c|c|c|}
\hline \multicolumn{9}{|l|}{ Physical Component } \\
\hline \multirow{2}{*}{ 1-Physical functioning } & \multicolumn{2}{|c|}{ Limited a lot } & \multicolumn{2}{|c|}{ Limited a little } & \multicolumn{2}{|c|}{ Not limited at all } & \multicolumn{2}{|c|}{ Total } \\
\hline & No & $\%$ & No & $\%$ & No & $\%$ & No & $\%$ \\
\hline - Limitation of the vigorous activities & 164 & 82 & 36 & 18 & 0 & 0 & 200 & 100 \\
\hline - Limitation of the moderate activities & 76 & 38 & 81 & 40.5 & 43 & 21.5 & 200 & 100 \\
\hline - Limitation of the slight activities & 31 & 15.5 & 99 & 49.5 & 70 & 35 & 200 & 100 \\
\hline \multirow{2}{*}{ 2- Role limitation -physical } & \multicolumn{2}{|c|}{ all of the time } & \multicolumn{2}{|c|}{ Some of the time } & \multicolumn{2}{|c|}{ Non of the time } & \multicolumn{2}{|c|}{ Total } \\
\hline & No & $\%$ & No & $\%$ & No & $\%$ & No & $\%$ \\
\hline $\begin{array}{l}\text { - Limited ability to spend the same amount of time } \\
\text { in performing activities as before }\end{array}$ & 108 & 54 & 76 & 38 & 16 & 8 & 200 & 100 \\
\hline - Difficult to perform needed work & 104 & 52 & 86 & 43 & 10 & 5 & 200 & 100 \\
\hline - Accomplished less than you would like & 99 & 49.5 & 84 & 42 & 17 & 8.5 & 200 & 100 \\
\hline - Performing limited kinds of activities & 65 & 32.5 & 106 & 53 & 29 & 14.5 & 200 & 100 \\
\hline \multirow{2}{*}{ 3-Bodily pain } & \multicolumn{2}{|c|}{ No pain } & \multicolumn{2}{|c|}{ Moderate } & \multicolumn{2}{|c|}{ Severe } & \multicolumn{2}{|c|}{ Total } \\
\hline & No & $\%$ & No & $\%$ & No & $\%$ & No & $\%$ \\
\hline $\begin{array}{l}\text { - How much bodily pain did you feel during the } 4 \\
\text { past week }\end{array}$ & 45 & 22.5 & 96 & 48 & 59 & 29.5 & 200 & 100 \\
\hline \multirow{2}{*}{$\begin{array}{l}\text { - During the past } 4 \text { weeks, how much did pain } \\
\text { interfere with your normal work }\end{array}$} & \multicolumn{2}{|c|}{ Not at all } & \multicolumn{2}{|c|}{ Quit abit } & \multicolumn{2}{|c|}{ Extremely } & \multicolumn{2}{|c|}{ Total } \\
\hline & 49 & 24.5 & 42 & 21 & 109 & 54.5 & 200 & 100 \\
\hline \multirow{2}{*}{ 4-General health } & \multicolumn{2}{|c|}{ True } & \multicolumn{2}{|c|}{ I don't know } & \multicolumn{2}{|c|}{ False } & \multicolumn{2}{|c|}{ Total } \\
\hline & No & $\%$ & No & $\%$ & No & $\%$ & No & $\%$ \\
\hline - Seem to get sick a little easier than other people & 85 & 42.5 & 21 & 10.5 & 94 & 47 & 200 & 100 \\
\hline - As healthy as anybody I know & 35 & 17.5 & 15 & 7.5 & 150 & 75 & 200 & 100 \\
\hline - Expect my health to get worse & 70 & 35 & 126 & 63 & 4 & 2 & 200 & 100 \\
\hline \multirow[t]{2}{*}{ - Health is excellent } & 3 & 1.5 & 14 & 7 & 183 & 91.5 & 200 & 100 \\
\hline & \multicolumn{2}{|c|}{ Excellent } & \multicolumn{2}{|c|}{ Good } & \multicolumn{2}{|c|}{ Poor } & \multicolumn{2}{|c|}{ Total } \\
\hline - Self-assessment of health & 0 & 0 & 75 & 37.5 & 125 & 62.5 & 200 & 100 \\
\hline & & & & me & & & & \\
\hline $\begin{array}{l}\text { - - Health status compared to one year ago } \\
\text { (change in health) }\end{array}$ & 3 & 1.5 & 32 & 16 & 165 & 82.5 & 200 & 100 \\
\hline
\end{tabular}

Table (4b): Distribution of the study subjects according to the generic HRQOL SF 36

\section{Mental component}

\section{5- Vitality}

- Feel full of life

- Have enough energy

- Feel have worn out

- Feel tired

\section{6- Social functioning}

- How much of the time has your health condition interfered with your social activities

\begin{tabular}{cccccccc}
\multicolumn{2}{l}{ all of the time } & \multicolumn{2}{l}{ Some of the time } & \multicolumn{2}{l}{$\begin{array}{l}\text { None of the } \\
\text { time }\end{array}$} & \multicolumn{2}{c}{ Total } \\
\hline No & $\%$ & No & $\%$ & No & $\%$ & No & $\%$ \\
\hline 4 & 2 & 77 & 38.5 & 119 & 59.5 & 200 & 100 \\
7 & 3.5 & 85 & 42.5 & 108 & 54 & 200 & 100 \\
61 & 30.5 & 96 & 48 & 43 & 21.5 & 200 & 100 \\
59 & 29.5 & 105 & 52.5 & 63 & 18 & 200 & 100 \\
\hline No & $\%$ & No & $\%$ & No & $\%$ & No & $\%$
\end{tabular}

- To what extent has your health condition interfered with all of the time Some of the time None of the Total

time
normal activities

\section{7-Mental health}

How much time during the 4 past weeks felt the following

$\begin{array}{llllllll}60 & 30 & 73 & 36.5 & 66 & 33 & 200 & 100\end{array}$

\begin{tabular}{rrrrrrrr}
60 & 30 & 73 & 36.5 & 66 & 33 & 200 & 100 \\
\hline \multicolumn{2}{c}{ Not at all } & \multicolumn{2}{c}{ Quit abit } & \multicolumn{2}{c}{ extremely } & \multicolumn{2}{c}{ Total } \\
\hline 70 & 35 & 79 & 39.5 & 51 & 25.5 & 200 & 100
\end{tabular}

all of the time Some of the time None of the Total

$\begin{array}{cccccccc}\text { No } & \% & \text { No } & \% & \text { No } & \% & \text { No } & \%\end{array}$

- Felt so down in the dumps (nothing could cheer you up)?

$\begin{array}{lllll}92 & 46 & 95 & 47.5 & 13\end{array}$

$6.5-200-100$

- Felt calm and peaceful

- Felt downhearted or depressed

- Been happy

Mental component

$\begin{array}{llllllll}7 & 3.5 & 85 & 42.5 & 108 & 54 & 200 & 100\end{array}$

$\begin{array}{llllllll}65 & 32.5 & 116 & 58 & 19 & 9.5 & 200 & 100\end{array}$

\section{Role limitation- emotional}

- Cut down the amount time you spent on work

- Accomplished less than you would like

10.5

$\begin{array}{llll}0.5 & 35 & 17.5 \quad 164\end{array}$

all of the time Some of the time None of the time Total

- did work or other activity less carefully than usual

\begin{tabular}{cccccccc} 
No & $\%$ & No & $\%$ & No & $\%$ & No & $\%$ \\
\hline 35 & 17.5 & 127 & 63.5 & 38 & 19 & 200 & 100 \\
41 & 20.5 & 119 & 59.5 & 40 & 20 & 200 & 100 \\
37 & 18.5 & 117 & 58.5 & 46 & 23 & 200 & 100
\end{tabular}


Table (5): The generic health related quality of life of the, physical and mental component of the study subjects

\begin{tabular}{|c|c|c|c|c|c|c|c|c|c|c|c|}
\hline \multicolumn{7}{|c|}{ Physical component } & \multicolumn{5}{|c|}{ Mental component } \\
\hline \multicolumn{2}{|c|}{ High } & \multicolumn{2}{|c|}{ Moderate } & \multicolumn{2}{|c|}{ Low } & \multicolumn{2}{|c|}{ High } & \multicolumn{2}{|c|}{ Moderate } & \multicolumn{2}{|c|}{ Low } \\
\hline No & $\%$ & No & $\%$ & No & $\%$ & No & $\%$ & No & $\%$ & No & $\%$ \\
\hline 0 & 0 & 169 & 84.5 & 31 & 15.5 & 23 & 11.5 & 177 & 88.5 & 0 & 0 \\
\hline
\end{tabular}

Table (6): Relationship between socio demographic data and subjects' level of knowledge regarding the disease

\begin{tabular}{|c|c|c|c|c|c|c|c|}
\hline & \multirow{2}{*}{ socio-demographic data } & & \multicolumn{2}{|c|}{ Total level of knowledge score } & \multirow[b]{2}{*}{ Poor(37) } & & \multirow{2}{*}{$\begin{array}{c}\text { FET } \\
\mathrm{P} \\
\end{array}$} \\
\hline & & & Good(10) & Moderate(153) & & Total 200 & \\
\hline \multirow{6}{*}{$\underset{\infty}{\infty}$} & \multirow{2}{*}{$60-$} & Count & 7 & 110 & 24 & 141 & \multirow{6}{*}{$\begin{array}{l}2.045 \\
0.727\end{array}$} \\
\hline & & $\%$ & 5 & 78 & 17 & 100 & \\
\hline & \multirow{2}{*}{$65-$} & Count & 3 & 37 & 10 & 50 & \\
\hline & & $\%$ & 6 & 74 & 20 & 100 & \\
\hline & \multirow{2}{*}{$70+$} & Count & 0 & 6. & 3. & 9 & \\
\hline & & $\%$ & 0 & 66.7 & 33.3 & 100 & \\
\hline \multirow{4}{*}{ 㐫 } & \multirow{2}{*}{ Male } & Count & 4. & 58 & 58 & 120 & \multirow{4}{*}{$\begin{array}{c}6.930 \\
0.031 *\end{array}$} \\
\hline & & $\%$ & 48.3 & 48.3 & 3.4 & 100 & \\
\hline & \multirow{2}{*}{ Female } & Count & 6 & 50 & 24 & 80 & \\
\hline & & $\%$ & 7.5 & 62.5 & 30 & 100 & \\
\hline \multirow{10}{*}{ 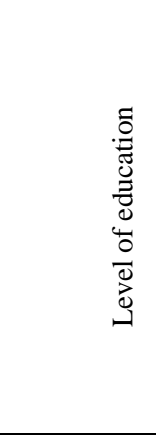 } & \multirow{2}{*}{ Illiterate } & Count & 2 & 62 & 29 & 93 & \multirow{10}{*}{$\begin{array}{l}47.155 \\
0.000^{*}\end{array}$} \\
\hline & & $\%$ & 2.1 & 66.7 & 31.2 & 100 & \\
\hline & \multirow{2}{*}{ Read and write } & Count & 0 & 18 & 3 & 21 & \\
\hline & & $\%$ & 0 & 85.7 & 14.3 & 100 & \\
\hline & \multirow{2}{*}{ Basic education } & Count & 2 & 40 & 5 & 47 & \\
\hline & & $\%$ & 4.3 & 85.1 & 10.6 & 100 & \\
\hline & \multirow{2}{*}{ Secondary } & Count & 2 & 26 & 0 & 28 & \\
\hline & & $\%$ & 7.1 & 92.9 & 0 & 100 & \\
\hline & \multirow{2}{*}{$\begin{array}{l}\text { University and } \\
\text { higher }\end{array}$} & Count & 4 & 7 & 0 & 11 & \\
\hline & & $\%$ & 36.3 & 63.7 & 0 & 100 & \\
\hline \multirow{10}{*}{  } & \multirow{2}{*}{ Farmer } & Count & 3. & 49 & 12. & 64 & \multirow{10}{*}{$\begin{array}{l}35.063 \\
0.000 *\end{array}$} \\
\hline & & $\%$ & 4.7 & 67.6 & 18.8 & 100 & \\
\hline & \multirow{2}{*}{ Employee } & Count & 4. & 54 & 3. & 61 & \\
\hline & & $\%$ & 6.6 & 88.5 & 4.9 & 100 & \\
\hline & & Count & 0 & 41 & 19 & 60 & \\
\hline & House wife & $\%$ & 0 & 68.3 & 31.7 & 100 & \\
\hline & & Count & 1 & 7 & 3 & 11 & \\
\hline & Manual worker & $\%$ & 9.1 & 63.6 & 27.3 & 100 & \\
\hline & & Count & 2 & 2 & 0 & 4 & \\
\hline & Private job & $\%$ & 50 & 50 & 0 & 100 & \\
\hline & & Count & 2 & 59 & 16 & 77 & \\
\hline$\stackrel{\mathscr{\Xi}}{0}$ & $<500$ & $\%$ & 2.6 & 76.6 & 20.8 & 100 & \\
\hline.$\Xi$ & 500 & Count & 5 & 87 & 16 & 108 & 16.220 \\
\hline$\vec{\lambda}$ & $500=$ & $\%$ & 4.6 & 80.6 & 14.8 & 100 & $0.000 *$ \\
\hline 苂 & $1000_{+}$ & Count & 3 & 7 & 5 & 15 & \\
\hline$\Sigma$ & $1000+$ & $\%$ & 20 & 46.7 & 33.3 & 100 & \\
\hline & & Count & 7 & 96 & 12 & 115 & \\
\hline & Urban area & $\%$ & 6.1 & 83.5 & 25 & 100 & 11.876 \\
\hline Residence & & Count & 3 & 57 & 25 & 85 & $0.003 *$ \\
\hline & Rural area & $\%$ & 3.5 & 67.1 & 29.4 & 100 & \\
\hline
\end{tabular}

* The difference is statistically significant at $\mathrm{P} \leq 0.05$ 
Table (7a) shows the relationship between sociodemographic data and the physical component of generic health related quality of life of the study subjects. $75 \%$ of the study subjects who had a moderate HRQOL- physical component were at age group 60 to less than 65 years. The table shows that age has a significant effect on the generic HRQOL- physical component $\mathrm{p}=0.000$. Although males reported a higher quality of life physical component than women, but there was not statistical significant differences, $\mathrm{p}=0.338$ was found.
$83.4 \%$ of the married subjects had a moderate generic HRQOL- physical component and marital status seems to affect generic HRQOL- physical component significantly $\mathrm{P}=0.009$. the same table revealed that, $97.5 \%$ of the study subjects who lived with their families members had a better HRQOL- physical component than those who lived alone and a statistical significant relation was observed $\mathrm{P}=0.010$. Generic HRQOL - physical impact was not significantly affected by living area and the setting of the study, $\mathrm{P}=0.729,0.264$ respectively.

Table (7a): Relationshipbetween socio-demographic data and the generic HRQOL- physical component .

\begin{tabular}{|c|c|c|c|c|c|c|}
\hline \multirow{3}{*}{\multicolumn{2}{|c|}{ Socio- demographic data }} & \multicolumn{4}{|c|}{ Generic HRQOL-Physical component } & \multirow{3}{*}{$\begin{array}{l}\mathrm{X} 2 \\
\mathbf{P}\end{array}$} \\
\hline & & \multicolumn{2}{|c|}{ Moderate } & \multicolumn{2}{|l|}{ Low } & \\
\hline & & NO & $\%$ & NO & $\%$ & \\
\hline \multirow{3}{*}{ Age } & $1-60-$ & 127 & 75.1 & 14 & 45.2 & \multirow{3}{*}{$\begin{array}{l}22.944 \\
0.000 *\end{array}$} \\
\hline & $2-65-$ & 39 & 23.1 & 11 & 35.5 & \\
\hline & $3-70+$ & 3 & 1.8 & 6 & 19.4 & \\
\hline \multirow{2}{*}{ Sex } & 1-Male & 99 & 58.6 & 21 & 67.7 & \multirow{2}{*}{$\begin{array}{l}0.916 \\
0.338\end{array}$} \\
\hline & 2-Female & 70 & 41.4 & 10 & 32.3 & \\
\hline \multirow{3}{*}{ M. status } & 1-Married & 141 & 83.4 & 20 & 64.5 & \multirow{3}{*}{$\begin{array}{l}9.454 \\
0.009\end{array}$} \\
\hline & 2-Widowed & 23 & 13.6 & 11 & 35.5 & \\
\hline & 3-Divorced & 5 & 3 & 0 & 0 & \\
\hline \multirow{5}{*}{ 氖 } & 1-Illiterate & 77 & 45.6 & 16 & 51.6 & \multirow{5}{*}{$\begin{array}{l}7.532 \\
0.110\end{array}$} \\
\hline & 2-Read and write & 18 & 10.7 & 3 & 9.7 & \\
\hline & 3-Basic education & 36 & 21.3 & 11 & 35.5 & \\
\hline & 4-Secondary & 27 & 16.0 & 1 & 3.2 & \\
\hline & 5-University and higher & 11 & 6.5 & 0 & 0 & \\
\hline \multirow{5}{*}{ 苞 } & 1-Farmer & 52 & 30.8 & 12 & 38.7 & \multirow{5}{*}{$\begin{array}{l}1.874 \\
0.764\end{array}$} \\
\hline & 2-employee & 51 & 30.2 & 10 & 9.7 & \\
\hline & 3-House wife & 52 & 30.8 & 8 & 25.8 & \\
\hline & 4-Manual worker & 10 & 5.9 & 1 & & \\
\hline & 5-Private job & 4 & 2.4 & 0 & .0 & \\
\hline \multirow{3}{*}{ Monthly income } & $1-<500$ & 52 & 30.8 & 12 & 38.7 & \multirow{3}{*}{$\begin{array}{l}4.464 \\
0.100\end{array}$} \\
\hline & $2-500-$ & 51 & 30.2 & 10 & 9.7 & \\
\hline & $3-1000+$ & 52 & 30.8 & 8 & 25.8 & \\
\hline \multirow{2}{*}{ Living condition } & 1-With family & 165 & 97.5 & 29 & 93.5 & \multirow{2}{*}{$\begin{array}{l}11.270 \\
0.010 \text { * }\end{array}$} \\
\hline & 2-Alone & 4 & 2.4 & 2 & 6.5 & \\
\hline \multirow{2}{*}{ Living area } & 1-Urban & 100 & 59.2 & 15 & 48.4 & \multirow{2}{*}{$\begin{array}{l}0.633 \\
0.729\end{array}$} \\
\hline & 2-Rural & 69 & 40.8 & 16 & 51.6 & \\
\hline \multirow{3}{*}{ Study setting } & 1-El- kabbary & 72 & 42.6 & 12 & 38.7 & \multirow{3}{*}{$\begin{array}{l}1.247 \\
0.264\end{array}$} \\
\hline & 2-Health insurance & 49 & 29 & 8 & 25.8 & \\
\hline & 3-Shark elmadena & 48 & 28.4 & 11 & 35.5 & \\
\hline
\end{tabular}

* The differences is statistically significant at $\mathrm{P} \leq 0.05$ 
Table (7b) shows the relationship between sociodemographic data and mental component of the generic HRQOL. Mental component were not significantly affected by age, $\mathrm{P}=0.472$ but 78.3 of those who had a high HRQOL - mental component were at age group 60 to less than 65 years. Sex and marital status although did not significantly affect HRQOL- mental component, but men and married subjects had a higher quality of life - mental component. Regarding the education the same table revealed that $47.5 \%$ of the study subjects had a moderate HRQOL mental component, this percent dropped into $22 \%$ for those who had basic education. Monthly income and occupation before retirement did not significantly affect HRQOL-mental component $\mathrm{P}=0.428,0.370$ respectively but the study subjects who lived in urban area had a better HRQOL- mental component than those who lived in rural areas.

Table (8) shows the relationship between study subjects' knowledge and the generic health related quality of life physical and mental component. The table shows that knowledge is positively associated with the HRQOLphysical component, having knowledge increased the HRQOL- physical component. Moderate HRQOLphysical component was reported by $95 \%, 78 \%$ and $66.7 \%$ for good, fair and poor knowledge level respectively. Statistically significant differences was found between subjects' level of knowledge and the generic HRQOL- physical component, $\mathrm{P}=0.002$. However no statistical significant differences were found between knowledge level and the HRQOL- mental component.

Table (7b): Relationship between socio-demographic data and the generic HRQOL- mental component

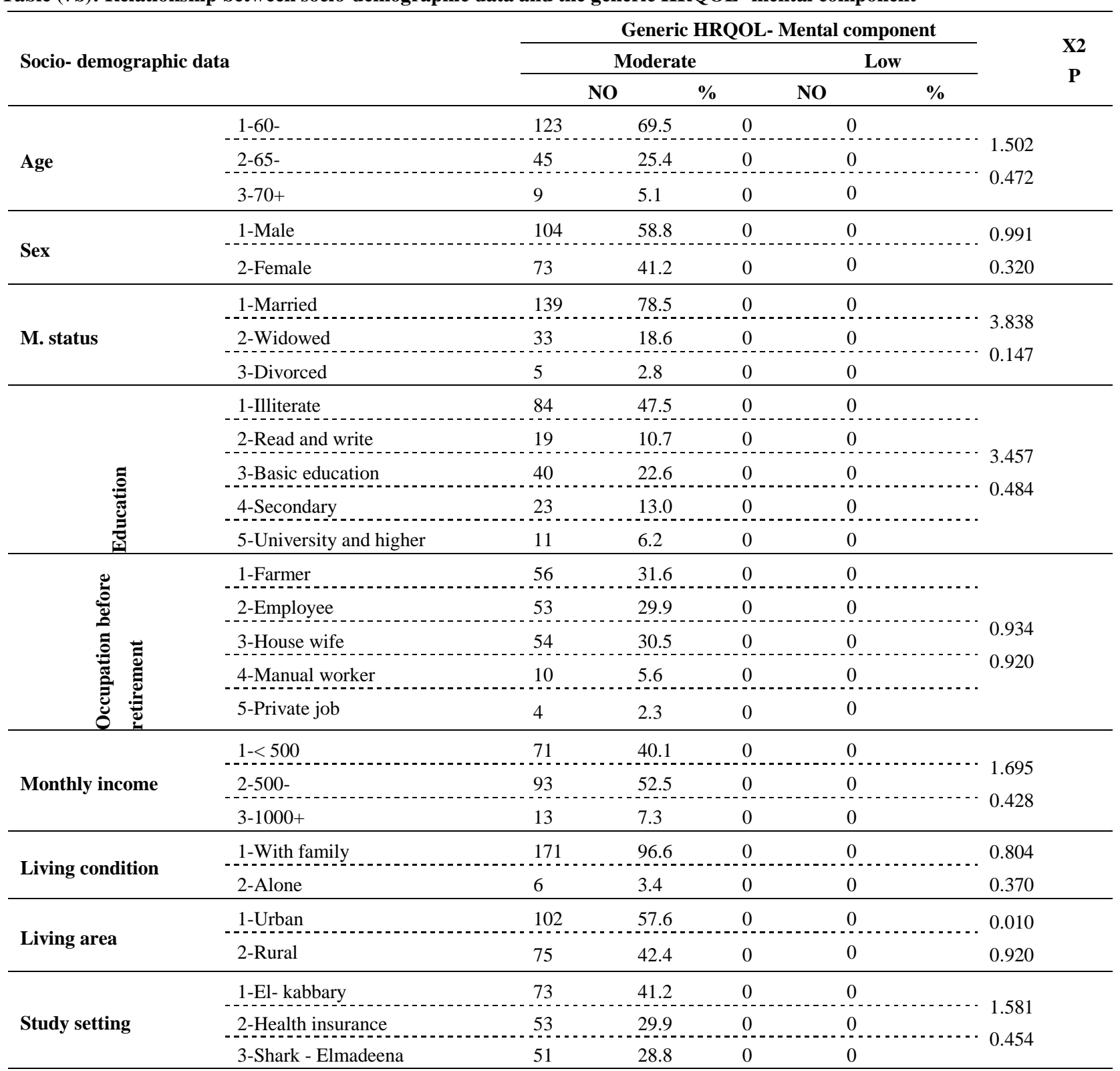

* The difference is statistically significant at $\mathrm{P} \leq 0.05$ 
Table (8): Relationship between study subjects' knowledge and the generic HRQOL

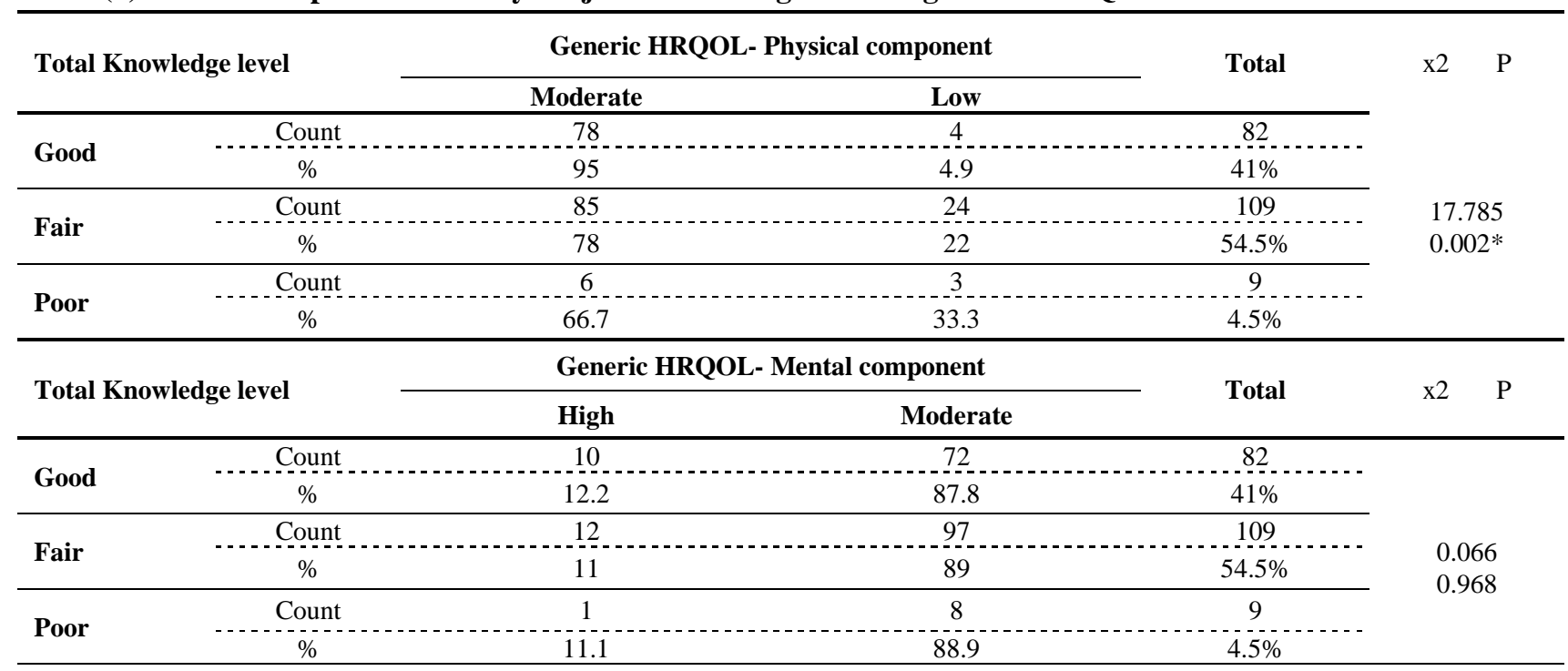

$*$ The difference is statistically significant at $\mathrm{p}<0.05$

\section{DISCUSSION}

Hepatitis $\mathrm{C}$ is a major public health problem affecting approximately $3 \%$ of the global population. Egypt has possibly the highest HCV prevalence in the world; $10 \%$ $20 \%$ of the general populations are infected. ${ }^{(29)}$

Chronic HCV infection is associated with decreased HRQOL. Although HCV has been suggested to directly impair HRQOL, other factors may also play a role. In this study, the factors possible to influence health related quality of life were classified into socio- demographic, physical and psychological factors. Therefore, the aim of the study was to determine factors influencing health related quality of life of geriatric patients with chronic hepatitis $\mathrm{C}$ virus. ${ }^{(30)}$

$\mathrm{HCV}$-specific knowledge aiming at better perception or improvement of behaviors can be critical to public health efforts to prevent disease transmission and to reduce HCV - related disability. ${ }^{(31)}$ In the present study, patients' knowledge about the disease was studied comprehensively; the majority of the studied subjects had moderate level of knowledge regarding chronic hepatitis C. Nearly one half of the participants had a partial knowledge about the virus, risk factors and vaccination. Regarding subjects knowledge about mode of HCV transmission, the majority of them had a good level of knowledge. On the contrary, a study done in Saudi Arabia 2008 reported that the study subjects had fair knowledge about the virus mode of transmission. (32) The majority of the study subjects have poor level of knowledge regarding $\mathrm{HCV}$ transmission by breast feeding and from pregnant mother to her fetus during pregnancy. This result is similar to other studies. The first study was conducted in Alexandria 2012 and reported that less than one third of the participants knew that the disease could be transmitted from mother to her fetus during pregnancy and during labor. The same finding was reported in Saudi Arabia 2008. ${ }^{(32,33)}$
As for factors affecting subjects' knowledge about chronic hepatitis $\mathrm{C}$, a positive relationship was found in the present study between participants' educational level and the level of specific knowledge regarding HCV. It means that the higher level of education was found to increase the awareness of the participants about the disease. This result was in the same line with the result of the study done in Saudi Arabia 2008. (32) Other factors such as living area and occupation before retirement partially influenced level of participants' awareness about the disease.]

Successful aging encompasses multiple dimensions of health, including physical, mental, and social well-being. It has been shown that even in the absence of liver cirrhosis, chronic infection with $\mathrm{HCV}$ impairs health related quality of life with profound negative impact on both physical and mental well-being. ${ }^{(34)}$ The results of the present study showed that physical component scale of the generic HRQOL - SF36 was more affected than mental component (table 7). These results are in the same line with several reports demonstrating a physical component more diminished than a mental component of the quality of life in chronic liver disease including HCV. ${ }^{(35,36)}$ Regarding the dimension of physical component of generic HRQOL scale, the result obviously observed that the physical functioning was strongly affected; this can be rationalized by the associated symptoms or by the negative impact of age related changes on musculoskeletal system. All study subjects did not consider that their health status is excellent and the majority of them had worse health status than one year ago. In contrary to a study done in the USA 2008 which found that, two thirds of the study subjects reported the same health status as one year ago. ${ }^{(37)}$ This disagreement in the results may be due to the subjects' age group and other socioeconomic predictors. Concerning role limitation- physical ( table 5) the present study revealed that more than one half of the study subjects suffered from role limitations due to impaired physical health. 
These results are in contrast with a study done in Alexandria 2011, and in the USA 2008. ${ }^{(28,37)}$ The reason for these differences in results can be attributed to the age of the participants as older adult patients with chronic HCV suffer from role limitations more than adult patients. Regarding bodily pain ( table $4 \mathrm{a}$ ), more than one quarter of the study subjects reported sever pain during the last 4 weeks and nearly one half of them reported a moderate pain. These results are similar to a study done in Alexandria 2011. Bodily pain is a subjective variable. More than three quarters of the study subjects in the present study reported moderate or extreme effect of bodily pain on performance of their normal work and most of them reported severe interference of pain with their daily living activities. These findings are in the same direction with the results of a study conducted in the USA $2006^{(38)}$ which reported that a majority of the subjects reported pain symptoms, which indicates that pain is a significant problem in patients diagnosed with HCV. Moreover, patients with $\mathrm{HCV}$ reported that their pain symptoms interfered with their daily activities and relationships. ${ }^{(38)}$

Concerning the mental component of generic HRQOL, the majority of the study subjects had a moderate reduction in mental component of SF-36 (table 4b). This result is consistent with other studies conducted in Egypt by Basal et al 2011 (34) and in the USA 2008, ${ }^{(37)}$ As for vitality, the present study found that more than half of the study subjects reported (not feeling full of life, not having enough energy and felt worn out and tired all of the time). These findings are in line with Martin's results $2008{ }^{(37)}$ which can be rationalized that older adults often suffer from lack of energy due to age related changes. As regards mental health, more than one half of the study subjects had been very nervous for some of the time during the 4 last weeks, more than one half of the study subjects did not feel calm and peaceful all the time during the last 4 weeks and felt downhearted or depressed for some of the time and the majority of the study subjects did not feel happy. The previous results revealed a moderate decrease in mental health among older adults in comparison with other studies ${ }^{(19,39)}$. These results can be rationalized by the increasing psychosocial stressors facing the elders regarding the age related changes which consequently can increase the impairment of mental wellbeing.

Older adults often suffer from multiple social problems associated with the aging process. Thus, older adult patients are liable to have less family support and less income and more financial burden. Moreover, rising medical costs and declining socio-economic conditions further contribute to the deterioration of the patient's mental health and subsequently health related quality of life ${ }^{(40)}$. In the present study, nearly one half of the study subjects suffered from high social impact of HCV and the majority of them had financial problems which are expected after retirement. In contrary to the results of Ibrahim et al 2011 which found that, the study subjects had moderate social impact of HCV. ${ }^{(40)}$ This disagreement in the results of the two studies can be attributed to the age group because elder adults usually face various social problems rather than adults.
Half of the study subjects had a moderate spiritual impact as a result of HCV and the majority of them increased their religious activity. These results are in the same line with the results in Egypt 2011.(40) This can be due to increasing religiosity among the study subjects can be considered a normal phenomenon in the eastern culture.

To achieve the ultimate goal of improving the health of geriatric patients with chronic $\mathrm{HCV}$, it is important for the gerontological nurse to fully understand the current health status of the geriatric patients with chronic $\mathrm{HCV}$, their knowledge and behaviors related to $\mathrm{HCV}$; this can help her to develop better nursing strategies to improve health related quality of life of the geriatric patients with chronic HCV.

\section{CONCLUSION AND RECOMMENDATIONS}

From the findings of the present study, it can be concluded that, chronic HCV affected negatively most of the dimensions of patients' generic health related quality of life. The majority of the study subjects have only partial knowledge about the disease and its mode of transmission. Being married was positively related to better health related quality of life. Advancing age are longer duration of having the HCV are factors that affected negatively patients' health related quality of life Based on the findings of this study it can be recommended that the concept of HRQOL should be a topic included in the Gerontological nursing course. Training programs should be planned and offered on regular basis to health care providers in the hospitals to update their knowledge about $\mathrm{HCV}$ and improve their practice. These training programs should include measures to improve the HRQOL of geriatric patients with chronic HCV, such as the development of HRQOL assessment tool for elder adults with chronic HCV. Moreover, raising awareness of the public about HCV via media and schools' programs, and establish specific guidelines for older adults with $\mathrm{HCV}$ to insure the best health care for them. Furthermore, preparation of visual educational materials such as instructional booklet includes photo groups and illustration about mode of $\mathrm{HCV}$ transmission- that should be given to every geriatric patient in hospitals.

\section{REFERENCES}

1. World Health Organization. Hepatitis C Fact sheet, June 2011 available at http://www.who.int/mediacentre/factsheets/fs164/en retrieved on 2/1/2012.

2. Chuan- Chang S, Ko W, Wu S Peng C, Yang S. Factors associated with quality of life in chronic hepatitis $\mathrm{C}$ patients who received Interferon Plus Ribavirin therapy. J Formos Med Assoc 2008; 107 (6): 1200-10.

3. E-L Marcus and R Tur-Kaspa. Chronic Hepatitis C Virus Infection in Older Adults. CLIN INFECT DIS 2005; 41(11): 1606-12.

4. Baldo V, Floreani A, Menegon T. et al. Prevalence of antibodies against hepatitis $\mathrm{C}$ virus in the elderly: a Seroepidemiological study in a nursing home and in an open population. The Collaborative Group. Gerontology 2000; 46:194-98.

5. Miller R, Mindikoglu A, Hepatitis C in the elderly: Epidemiology, natural history and treatment. Clin Gastroenterol Hepatol 2009; 7(2):124-28. 
6. Alter MJ, Kruszon-Moran D, Nainan OV, et al. The prevalence of hepatitis $\mathrm{C}$ virus infection in the United States, 1988 through 1994. N Engl J Med 2009;341:556-62.

7. Armstrong GL, Simard EP, Wasley A, et al. The prevalence of hepatitis $\mathrm{C}$ virus infection in the United States 1999-2002 [abstract 31]. Hepatology 2004; 40 (Suppl 1):176A.

8. McHutchison JG. Understanding hepatitis C. Am J Manag Care 2004; 10(2 Suppl):S21-9.

9. Ben Yehuda A, Globerson A, Krichevsky S, et al. Ageing and the mismatch repair system. Mech Ageing Dev 2000; 121:173-9

10. Okayama A, Stuver SO, Tabor E, et al. Incident hepatitis $\mathrm{C}$ virus infection in a community-based population in Japan. J Viral Hepat 2002; 9:43-51.

11. Guadagnino V, Stroffolini $\mathrm{T}$, Rapicetta $\mathrm{M}$, et al. Prevalence, risk factors, and genotype distribution of hepatitis $\mathrm{C}$ virus infection in the general population: a community-based survey in southern Italy. Hepatology 1997; 26:1006-11.

12. Thabut D, Calvez SL, Thibault V, et al. Hepatitis C in 2410 patients 65 years or older: a severe and neglected curable disease [abstract 549]? Hepatology 2003; 38(Suppl 1): 424A.

13. El-Zanaty, F, Ann W. 2009. Egypt Demographic and Health Survey 2008. Cairo, Egypt: Ministry of Health, El-Zanaty and Associates, and Macro International available at: http://www2.hawaii.edu Retrieved on $6 / 11 / 2011$.

14. Schwarzinger M, Mohamed M, Gad R, Dewedar S, et $a l$. Risk perception and priority setting for intervention among hepatitis $\mathrm{C}$ virus and environmental risks: a cross-sectional survey in the Cairo community. BMC Public Health, 2010; 10:773.

15. Lehman E, Dynamics of liver diseases in Egypt. Published doctorate dissertation. USA, Michigan University: 2008.

16. HCV transmission and prevention in Egypt 2011 available at http://www.hepnile.org/index.php/g-hcvtransmission-and-prevention retrieved on 1-3-2012.

17. Schwarzinger M, Dwedar S, Rekacewicz C, et al . Chronic hepatitis $\mathrm{C}$ infection. Does it really impact Health related quality of life .A study in rural Egypt. Hepatology 2004; 40:1434 -41.

18. Mauss S, Berg T, RoCKstroh J, et al. Text book of hepatology. 2nd. Germany, Flying Publisher co: 2010; 19-31 and 60-81.

19. Khaled S. Heissam, Abass H. Quality of life for patient with HCV. Published research paper, Faculty of Medicine, Suez Canal University 2006. Available at: http://www.scribd.com/doc/38217146/Quality-of-Lifein-Patients-With-Hepatitis-C. Retrieved on 6-3-2011.

20. Halter J, Ouslander J,Tintti M, et al. Hazard's geriatric medicine and gerontology. 6th ed. USA: McGraw Hill Co: 2009; 1165-73.

21. Sommers M, Johnson S. Disease and disorders $3^{\text {rd }}$ ed. Philadelphia, Davis co: 2007: 413-23.

22. Wilhelmson $\mathrm{K}$, Anderson $\mathrm{CH}$. Ageing and society, Cambridge University Press; 2005:5.

23. Al-Awadhi A, Al-Jarallah K, Hasan F, et al. Rheumatic manifestations and immunological abnormalities in patients with chronic hepatitis C. A research study in the Middle East, School of Medicine, Kuwait University, Kuwait. Rev Rhum Engl Ed, 1998; 5(6):372-77.

24. Foster G, Goldin R, Thomas H. Chronic hepatitis C virus infection causes a significant reduction in quality of life in the absence of cirrhosis. Hepatology 1998; 27:209-12.

25. Sobhonslidsuk A, Silpakit C, Kongsakon R. Factors influencing health-related quality of life in chronic liver disease. World J Gastroenterol 2006; 12(48): 7786-91.

26. Linton A, Lach H, Gerontological Nursing concepts and practice 3rd ed. USA, Elsevier co: 2007 ;469-75.

27. Atiq, Gill M, Khokhar N. Quality of life assessment in Pakistani patients with chronic liver disease. Shifa International Hospital Islam-Abad. Journal of Medical Pakistani Association( JMPA)2004;54:113.

28. Tawfike E. Impact of educational program on health related quality of life HRQOL among virus hepatitis $\mathrm{C}$ patients. Unpublished doctorate dissertation, High Institute of Public Health, Alexandria University; Egypt 2011.

29. Minuk Y, Gutkin A, Wong G, Kaita D. Patient concerns regarding Chronic hepatitis $\mathrm{C}$ infections. Viral Hepatol $2005 ; 12: 50-7$.

30. Huser W, Zimmer C, Schiedermaier P, Grandt D. Biopsychosocial predictors of health-related quality of life in patients with chronic hepatitis C. PSYCHOSOM MED 2004; 66:954-58 .

31. Fraenkel L, McGraw S, Wongcharatrawee S, GarciaTsao G. Patients' experiences related to anti-viral treatment for hepatitis C. Patient Educ Couns, 2006;62: 148-55.

32. Asbri N. Hepatitis B and C knowledge among Saudi dental patients. Saudi med 2008; 29 (12): 1975-90 .

33. Hassan S, EL-Ghitany E, El-sheikh W. Knowledge, Attitude and Lifestyle Changes among Chronic Hepatitis C Patients in Alexandria, Egypt: A Fear-Appeal Intervention. AM SCI 2012; 8(2): 73-79.

34. Basal A, Kamel E, Nafady H. Studying the quality of life of chronic hepatitis $\mathrm{c}$ patients and the associated factors. AM SCI 2011; 7(12): 649-55.

35. Walsh K, Alexander G. chronic viral hepatitis. Post grad Med, 2001; 77(910):498-505.

36. El-Zayadi A, Selim O, Hamdy $\mathrm{H}$, et al. Impact of cigarette smoking on response to interferon therapy in chronic hepatitis C Egyptian patients. World J Gastroenterol 2004; 10: 663-6.

37. Martin L. Socio-demographic, clinical, and social influences on health- related quality of life individuals with hepatitis c (HCV). Published doctorate dissertation, Ohio University 2008.

38. Blasilo J, Shinkunas L, Labresque D, et al. Mental and physical symptoms associated with lower social support for patients with hepatitis C World J Gastroenterol 2006; 12(29): 4665-72.

39. Catherine F, Christiansen D, Nunes D, Heeren T, et al. "Health- related quality of life of patients with HIV Disease: impact of hepatitis C Co-infection." CLIN INFECT DIS 2004; 38:572-78.

40. Ibrahim E, Madian A. Impact of Hepatitis C on HealthRelated Quality of Life In Egypt. AM SCI 2011; 7(11): 430-9. 